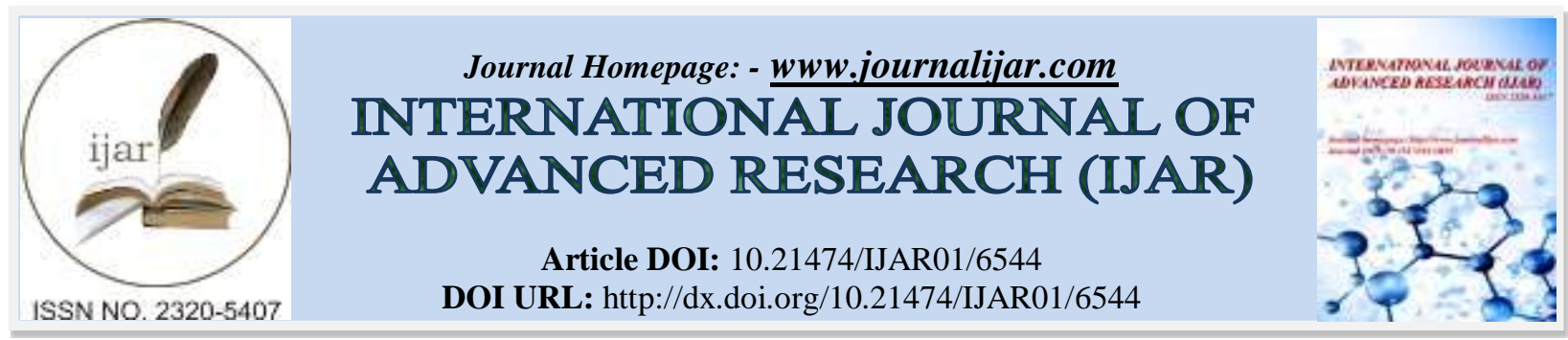

RESEARCH ARTICLE

\title{
SOCIAL DETERMINANTS INFLUENCING TRANSITION RATE OF GIRLS FROM PRIMARY EDUCATION TO SECONDARY EDUCATION IN KOIBATEK SUB-COUNTY, KENYA.
}

\author{
Gladys Jerono Koech, Dr. Joshua Odhiambo Ogal and Dr. Rachael Koros.
} Mount Kenya University, Kenya.

\section{Manuscript Info}

Manuscript History

Received: 15 December 2017

Final Accepted: 17 January 2018

Published: February 2018

Key words:-

Social, Determinants, Transition

Rate, Girls, Education.

\begin{abstract}
The ministry of education in Kenya has an overall goal to provide access to all levels of education irrespective of the social-economic status. Many recent research studies indicate that more girls have enrolled at all level of education for instance in the year 2001/2002 female enrolment at primary school level nationally was 49.3 percent of the whole population, 47.2 percent at secondary level and 32.2 percent at tertiary college. These findings show that transition rate of female decrease at each higher level of education. This study sought to investigate the influence of social determinants of transition rate of girls from primary to secondary education in Koibatek sub-county, Kenya. The study employed concurrent triangulation research design and targeted 91 head teachers and 2208 pupils. Simple random sampling was used to select 74 head teachers and 327 pupils. The study employed mixed methods approach. The data was collected using questionnaires and interviews. To ascertain the validity of research instrument, the researcher consulted experts and included their comments on instrument before data collection. To determine reliability of research instrument was piloted and a reliability coefficient calculated. A Reliability coefficient of 0.72 was obtained indicating that the instruments were reliable. To ascertain credibility and dependability of qualitative data the investigator certified that each respond in the research was reported in detail to allow an external investigator to repeat and achieve similar findings. Data was analysed using percentages, means and mode. In addition, Pearson Correlation analysis was used to test the study hypothesis. The study findings showed that $89.4 \%$ of the pupils believed that the involvement of girls in household chores at home influenced negatively their education. The study further found a significant and positive association $(\mathrm{r}=.807 ; \mathrm{p}=$ .008) between social determinants and girls transition to secondary education The findings of the study will provide planners, policy makers and administrators with better understanding of the nature and determinants of transition rate and assist in the ongoing search for access and efficiency in education, it will also provide a base for further research on transition rate to other educational levels.
\end{abstract}

Copy Right, IJAR, 2018,. All rights reserved. 


\section{Introduction:-}

Education transition rates can be defined as the percentage of learners advancing from one level of schooling to the next. It is calculated as the percentage of upcoming year divided by the number of learners in senior class in the preceding year (Hueblar, 2011). Education transition rates in education from primary school level to secondary school level worldwide show that eighty-five percent $(85 \%)$ of students who attain the highest class in primary school get access to secondary school education level. West and Central Africa have fifty-two percent transition rates making them to have the lowest transition rates in the world. However, transition rates are shown to be the highest in developed countries where on average have ninety-eight percent while countries in Eastern Europe have on average ninety-six percent transition rates (UNESCO, 2011).

Education is a fundamental human right because it empowers individuals with the knowledge and skills needed to increase production and income, as well as enabling individuals take advantage of employment opportunities in order to reduce poverty (UNESCO, 2010). Secondary education therefore plays a vital role in ensuring that a country's development through training, are pre-requisites to economic growth and Social development (World Bank, 2008). This is why governments all over the world are committed to the provision of education to their citizens.

In Latin America, Brazil has the highest secondary gross enrolment ratios at almost $100 \%$ compared to Guatemala where only $51 \%$ of students enroll beyond primary education. Only a handful of Sub-Saharan African countries, such as Botswana, Cape Verde, Mauritius and South Africa, have achieved rates of access to secondary education as high as $80 \%$ for junior secondary while Kenyan transition levels currently stands at around $73 \%$. Countries such as Burundi, Burkina Faso, and Rwanda have not even achieved rates of $20 \%$ (SEIA, 2007).

Ministry of Education (2003) noted that the Government of Kenya has been formulating guidelines which are geared towards the attainment of social equality and non-discrimination. In the Education sector, considerable effort has been made to ensure that regional special needs and access to education for girls are addressed. The Government of Kenya is also a party to key International Resolutions and treaties, these include, the Universal Declaration on Human Rights (1948), Convention of the Elimination of all Discrimination Against Women [CEDAW] (1979), Treaty on the Right of the Child [CRC] (1989), Beijing Declaration and Platform for Action (1995), Jomtien World Conference (1990), Dakar Framework of Action on EFA (2000), Millennium Development Goals (MDGs) and Goals of the African Union (G.O.K. 2005). These efforts are aimed at the realization of the Sustainable Development Goals (SDGs) and Education for All.

According to UN (2016) Goal 4 of the Sustainable Development Goals focuses on the attainment of initial and higher-order skills which include greater and more equitable access to technical and vocational education and training and higher education; training throughout life; and the knowledge, skills and values needed to function well and contribute to society. Therefore, the transition rate of girls in secondary schools should be high in order to achieve this goal.

According to GoK, (2005) secondary school section is facing numerous challenges ranging from low participation rate for girls to unsatisfactory levels of transition from primary school to secondary school education level. Studies revealed that key factors include cultural beliefs, social challenges, religious beliefs, perceptions towards girl-child education, poor socio-economic backgrounds of the parents, child labour, poor learning environments, lack of role models for girls, HIV/AIDS, curriculum, pedagogy and learners' attitudes (Guyo, 2013; Republic of Kenya (RoK), 2007). The government can realize the aim of providing access to educational opportunities by first establishing factor that hinder girls' advancement in education must be established and putting in place adequate strategies to minimize or eliminate these factors (Goodluck \& Odaro, 2011). Education policy and data centre in Koibatek SubCounty (2015) indicate that transition rate of girls from primary to secondary was at $48.8 \%$ as compared to that of boys which was at 88\% in 2014 (Koibatek Sub-County Education Office, 2014). To be more specific out of 2,000 girls that completed standard 8 only 956 girls were able to transit to form one. The transition rate for girls in 20 selected primary schools in the study area was tabulated. The information on the number of girls who sat for KCPE examinations and those who transited to form one was obtained from records given by the head teachers during the interview schedule.

Despite having several efforts including bursary schemes to support girls from poor background and establishment of girls' secondary schools among others low transition still persists. This research was undertaken to establish the 
influence of social factors on transition rate from primary school level to secondary education among girls in Koibatek Sub-County, Kenya.

\section{Aim of the Study}

The aim of this study was to establish social determinants of transition rate of girls from primary education to secondary education among girls in Koibatek Sub-County, Kenya.

\section{Hypotheses of the Study}

$\mathbf{H O}_{1}$ : There is no significant relationship between social determinants and transition rate of girls from primary education to secondary education in Koibatek Sub-County, Kenya.

\section{Literature Review}

Houston's (2004) research findings noted that enhancement of the parents' right in choosing schools for their children made them more inclined to invest themselves in their children's education. Because parents would be more involved, and there would be more association between home and school. At the same time, Teske, Fitzpatrick and Kaplan (2007) revealed that the parents who were more involved in the making the choice of the school had a higher degree of satisfaction with the school performance.

Parental involvement is important for students' social and emotional development as reported by Sanders \& Sheldon, (2009). Interestingly, students who have parents who are more involved in their education have been shown to have a higher motivation to achieve in school and a higher level of school engagement. Thus, parental involvement can affect the learner's academic achievement through the impact on the development of the learner's attitude and engagement with school, as well as a student's perception of their potential. With regards to transition between school levels, studies suggest that if measured in grades and test scores, students cope more successfully going into middle school and high school if they have involved parents who monitor their homework and discuss their school works frequently (Sanders \& Sheldon, 2009; Henderson \& Mapp, 2002; Sheldon, 2009).

Some parents consider educating girls as a worthless investment and fear that sending girls to school would disrupt their pattern of traditional life. Some parents regard girls as intrinsically inferior to boys and where there exists a belief that education is purchasable commodity and a better investment in a boy than a girl, girls become the first offering to the family budget when resources are scarce. A World Bank study (1988) revealed that the important social benefits derived from female education are not likely to have much impact on a family's private investment decision. In patrilineal, society the opportunity cost of a daughter's time when she is attending school and such other costs as school fees are borne by her parents, whereas the benefits of her education are thought to accrue principally to her future husbands' family. Abdulai (2005) reported that fathers do not wish to pay fees for their daughters; instead they would rather have them married off.

Educated parents are more motivated to seek and able to afford education for their children than uneducated (Chege, et al., 2006). Some study done on the causes of low enrolment and high dropout rate in primary education among female children in North Uganda showed that children whose parents are not educated experienced higher dropout rates and this was noted to be higher for female children whose mothers had no education (Ayiga, 1997).

Research has pointed out that most parents in Africa have traditional beliefs with preference of particular sex to education. High education priority is given to a boy child as compared to girl child (Nyawara, 2007). Anderson, as quoted by Chimombo (2005) observed that females have less access to education sector than males hence parents decide that schooling is not relevant for the economic roles of their female children who will move to their husband's families when they marry and that gains in productivity or income due to education will accrue to the families of their sons in law rather than to them (World Bank, 1995).

According to MOEST, the girl child in most regions lack role models. Information available at the Ministry of Education shows that female teachers in secondary schools account for approximately 30 per cent of the teaching staff in Kenya. Most of the female teachers teach in urban areas, leaving very few female teachers in the rural schools (GoK, 2007). Moreover, lack of adequate female teaching staff most secondary schools influences negatively girls' enrolment, retention and completion rate at secondary schools. Birdsall, Levine and Ibrahim (2005), in their study pointed out that there was a positive association between gender parity in secondary school 
retention and the percentage of the female teachers available in a school. This is attributed to the fact that female teachers are considered to be role models to the young girls.

According to a report by Alba de Souza, (2006), the proportion of girls going to school is about half that of the already low attendance of boys in the pastoralist areas. Like many other parents, pastoralist parents strongly prefer to send their daughters to schools having female teachers. The lack of female teachers is a challenge in most pastoralist areas. Additionally, the Education Ministry needed the help of pastoralists so that they could then help other pastoralists. In this study, lack of role models among girls influenced negatively their education especially the transition rate.

UNICEF (2009) report pointed out that addressing the educational rights and needs of Orphaned and Vulnerable Children (OVC) in Sub-Saharan Africa presents new openings and challenges that need to be addressed. With the eradication of school fees in public primary schools in Sub-Saharan Africa, most of the children from poor socioeconomic backgrounds are enrolled in schools. Nevertheless, the number of orphans and vulnerable children (OVC) has risen thus giving out new problems of dealing with the large numbers and in taking the necessary measures to address their educational rights and needs (UNICEF, 2009). Moreover, research by Fleming (2015) pointed out that OVC in countries with many cases of HIV/AIDS experienced discrimination in accessing education and healthcare as orphan hood is associated with HIV/AIDS. Fleming further noted that maternal and children who are double orphans are discriminated against more in accessing education than paternal orphaned children (Fleming, 2015; Case $\&$ Ardington, 2006). These orphans experience financial difficulties which further disadvantages from accessing education and obtaining education related materials.

Similarly, Hallfors et al., (2011) in their study noted that supporting adolescent girls to be retained in school enhances their opportunities of school retention, hence chances of contracting HIV as a result of early marriages is reduced. This interposition further decreases the likelihood of girls dropping out of school. These researchers maintain that retaining girls in schools enhances their bonding with school and teachers which in turn makes girls feel acknowledged and regarded by their instructors. This inspires the girl-child to work extra hard so as to realise a better life afterwards (Hallfors et al, 2011). On the other hand, Kelly (2002) posited that formal school education is a powerful instrument for changing poverty in an environment where HIV/AIDS is very rampart. He further noted that advancement in education reduces poverty in the society. All students need to be given quality education regardless of their socio-economic background thus equipping them with knowledge, skills and competencies that will later enhance their personal earnings and contribute to economic productivity (Baxen, et al., 2014; Robeyns, 2006). This study investigated the social determinants influencing transition rate of girls to secondary education in Koibatek Sub-County, Kenya.

\section{Research Methodology and Design}

The current study was based on mixed methods approach whereby the use of both qualitative and quantitative methods was used in data collection and analysis. A mixed research is an approach to inquiry that combines both quantitative and qualitative approaches. Besides, it involves the integration of philosophical assumptions, the use of both quantitative and qualitative strategies and the mixing of both strategies in a single study. Thus, it is more than simply collecting and analyzing both kinds of data but it also encompasses the use of both strategies in tandem so that the overall strength of a study is greater than either qualitative or quantitative approach alone (Creswell, 2009). In addition, the study employed concurrent triangulation research design using mixed methods of data collection and analysis. The design deals with the incidences, distributions and the relationship between various educational factors. It gathers data both quantitative and qualitative at a particular point in time with the intention of describing the nature of the existing conditions, identifying the standards against which existing conditions can be compared and determining the relationship that exists between specific events (Orodho, 2005). The design was adopted because it reduces differences or prejudice that the population studied, resulting to in-depth, rich and meaningful research findings.

The study targeted 91 public primary school head teachers and 2208 class eight pupils. Therefore, the target population was comprised of 2299 respondents. The sample size formula for this study is Krejcie and Morgan (1970) as cited in Kasomo (2001). The formula is given as:

$$
\mathrm{n}=\frac{X^{2} * N * P(1-P)}{\left(M E^{2} *(N-1)\right)+\left(X^{2} * P *(1-P)\right)}
$$


Where
$\mathrm{n}=$ Sample size
$\mathrm{X}^{2}=$ Chi Square for the specified confidence level at 1 degree of
freedom=
(3.841) from
tables
$\mathrm{N}=$ Population size
$\mathrm{P}=$ Population proportion (.50 in the table)
$\mathrm{ME}=$ Desired margin of error (expressed as a proportion $=0.05$ )

Using the formula, a sample size of 74 head teachers and 327 pupils was obtained. Simple random sampling was used to select the public primary school head teachers and pupils. This technique ensured that each sample had an equal and independent chance of being included in the sample. It also ensures that the sample is free from bias and prejudice.

The questionnaires and interview schedules were used to collect data from pupils and head teachers respectively. Kothari (2008), posits that questionnaires are typically free from the interview bias since the answers given are in respondents' own words. Additionally, Kothari (2008) observes that interview schedules are particularly suitable for intensive investigation. It ensures that the interviews are slightly flexible, sensitive and have high return rate of response.

Validity of the research instruments was ascertained by consulting thesis supervisors from the Department of Educational Management and Policy Studies, Mount Kenya University who are experienced in the research methodology. The research experts made criticism and comments on the format of the instruments. The comments were integrated while designing the research questionnaire before the final administration of the instruments to the study respondents. To establish the reliability of the research instruments, pilot study was carried out in two schools in the neighbouring sub-county believed to have the same characteristics as the research respondents. The research tools were given to the pilot set twice at an interval of two weeks. The results were compared using Spearman Rank Order correlation coefficient using SPSS program. A trustworthiness factor of 0.72 was obtained showing that the research tools were reliable as per Orodho (2009). Further, Credibility was achieved by triangulation method where information was collected from head teachers and pupils. This reduced the differences or prejudices that were held by respondents in various roles.

The collected data was analyzed using percentages, means and modes. In addition, Pearson Correlation analysis was used to test the relationship between the independent and dependent variables. Data was presented using distribution tables and graphical presentation.

\section{Results and Discussions}

The aim of this study was to identify social determinants influencing transition rate of girls to secondary education in Koibatek Sub-County. To attain this aim, pupils were asked to rate their degree of agreement or disagreement on a five-point Likert scale elements in the questionnaire on social determinants influencing transition rate of girls to secondary education. The results of data analysis are shown in Table 1.

Table 1:- Pupils' Responses on Social Determinants Influencing Transition Rate of Girls to Secondary Education

\begin{tabular}{|c|c|c|c|c|c|c|c|c|c|c|}
\hline \multirow[t]{2}{*}{ Statement } & \multicolumn{2}{|l|}{ SD } & \multicolumn{2}{|l|}{ D } & \multicolumn{2}{|l|}{ UD } & \multicolumn{2}{|l|}{$\mathbf{A}$} & \multicolumn{2}{|l|}{ SA } \\
\hline & $\mathbf{F}$ & $\%$ & $\mathbf{F}$ & $\%$ & $\mathbf{F}$ & $\%$ & $\mathbf{F}$ & $\%$ & $\mathbf{F}$ & $\%$ \\
\hline $\begin{array}{l}\text { Girls lack parent's } \\
\text { encouragement }\end{array}$ & 38 & 12.5 & 55 & 18.2 & 0 & 0.0 & 111 & 36.6 & 99 & 32.7 \\
\hline $\begin{array}{l}\text { Girls lack positive } \\
\text { role models }\end{array}$ & 46 & 15.2 & 129 & 42.6 & 4 & 1.3 & 75 & 24.8 & 49 & 16.2 \\
\hline $\begin{array}{l}\text { Religious beliefs } \\
\text { has negative impact } \\
\text { on girls education }\end{array}$ & 63 & 20.8 & 140 & 46.2 & 24 & 7.9 & 64 & 21.1 & 12 & 4.0 \\
\hline $\begin{array}{l}\text { HIV/AIDS has } \\
\text { negative impact on } \\
\text { girls education }\end{array}$ & 59 & 19.5 & 43 & 14.2 & 55 & 18.2 & 88 & 29.0 & 58 & 19.1 \\
\hline
\end{tabular}


Table 1 shows that $111(36.6 \%)$ pupils agreed with the statement that girls lacked parental encouragement leading to low transition to secondary education, $99(32.7 \%)$ learners strongly agreed with the statement and 55 (18.2\%) pupils disagreed with the statement while 38 (12.5\%) pupils strongly disagreed with the statement. The results of the research showed that $69.3 \%$ of the pupils in public primary schools in Koibatek Sub-County believed that girls lacked encouragement from their parents concerning education and therefore had low transition to secondary education. This finding was found to be similar to those of Ngware et al, (2009) who reported that parents' education level positively associated with student capability, which may in turn result into higher education attainment for the siblings. Moreover, parents with a higher level of education have a higher likelihood of offering a more conducive learning environment for their offspring at home and also encourage their transition to secondary schools. Furthermore, Kariuki, (2007) pointed out that the low level of enrolment of the girl-child in secondary schools was explained by the circumstance that nationwide, when learners failed to obtain good marks at primary level which enables him or her to secure a secondary school placement, parents are inclined to encourage boys to repeat class seven but are less enthusiastic to give the girl-child a second chance in education. This proposes greater parental worry for boys to advance to higher education levels in comparison to girls.

In addition, $129(42.6 \%)$ pupils disagreed with the statement that girls lacked positive role models in education dropping out of secondary education, 75 (24.8\%) pupils agreed with the statement, 49 (16.2\%) pupils strongly agreed with the statement and $46(15.2 \%)$ pupils strongly disagreed with the statement while $4(1.3 \%)$ pupils were undecided on the statement. The study findings showed that $57.8 \%$ of the pupils in public primary schools believed that girls had positive role models. However, it has been noted that lack of adequate female educators in secondary schools also affected girls' enrolment, retention and completion of secondary education. As pointed out by Birdsall, Levine and Ibrahim (2005), there is a significant positive association between gender equality in retention and the proportion of female teachers. This is attributed to the fact that female teachers act as role models to the young girls. Additionally, the parents feel secure sending their girls to schools with at least a female teacher. They trust that their girls will be protected and counseled accordingly by a female teacher.

Further, $140(46.2 \%)$ pupils disagreed with the statement that religious beliefs have negative impact on girls' education, $63(20.8 \%)$ pupils strongly disagreed with the statement, $64(21.1 \%)$ pupils agreed with the statement and $24(7.9 \%)$ pupils were undecided on the statement while $12(4.0 \%)$ pupils strongly agreed with the statement. The study findings showed that $67.0 \%$ of the pupils in primary schools in Koibatek Sub-County believed that religious beliefs had a positive impact on girl child education. This implies that religion promotes education of girl child.

Interviews conducted with the heads of various schools showed that parents who had low level of education in the region did not bother sending their children especially the girl child. In addition, the level of poverty in the area contributed to girl child dropout in education. This shows that pupils especially girls who came from poor socioeconomic backgrounds dropped out of school due to lack of school fees and basic necessities for use in school. Additionally, Drummond and Stipek, (2004) while deliberating on low income parents' belief about their role in sibling's academic learning noted that some parents pointed out that their tasks were limited to meeting offspring's basic and emotional needs. These parents' narrow view toward their responsibilities in the educational achievement of their children and scarcity of fund to intensify such processes could be a challenge to their children's success. This implies that education of girls who are from poor socio-economic backgrounds could be negatively affected leading to low transition rates of girls.

The hypothesis of this study stated that:

$\mathbf{H 0}_{1}$ : There is no significant relationship between social determinants and transition rate of girls to secondary education in Koibatek Sub-County.

The hypothesis of this research was attained through the use of Pearson Correlation Coefficient at $p \leq 0.05$ significance level. The outcomes of the analyzed information are presented in Table 3. This was grounded on Amin's (2005) strategy which underscores that at 0 there is no association, above 0 to .2 it is a very weak association, above .2 to .4 it is a weak association, above .4 to .6 it is a moderate association, above .6 to .8 it is a strong association, and above .8 to 1 it is a very strong association. Additionally, the negative values suggest negative association as enumerated above. 
Table 2:- Relationship between Social Determinants Transition Rate of Girls to Secondary Education

\begin{tabular}{|l|l|}
\hline & Transition to Secondary Education \\
\hline Social Determinants & $\mathrm{r}=.807^{*}$ \\
& $\mathrm{p}=.008$ \\
$\mathrm{n}=303$
\end{tabular}

* Significant,

Table 2 illustrates a significant and a very strong positive association $(r=.807 ; p=.008)$ between social determinants and girls transition to secondary education. Therefore, the hypothesis that "there was no significant relationship between social determinants and transition rate of girls to secondary education in Koibatek SubCounty" was rejected. For this reason, the alternative hypothesis that "there is statistically significant relationship between social determinants and transition rate of girls to secondary education". Hence there exist a statistically significant relationship between social determinants and transition rate of girls to secondary education.

On interviewing the head teachers, it emerged that parents who had low level of education in the region did not bother sending their children especially the girl child. In addition, the level of poverty in the area contributed to girl child dropout in education. This shows that pupils especially girls who came from poor socio-economic backgrounds dropped out of school due to lack of school fees and basic necessities for use in school. Drummond and Stipek, (2004) while discussing their "low income parents" belief about their role in children's academic learning mentioned that a few of these parents indicated that their responsibilities were limited to meeting children's basic and social emotional needs, such as providing clothing, emotional support and socializing manners. So, these parents' shortsightedness toward their responsibilities in the educational achievement of their children and scarcity of fund to intensify such processes could be a challenge to their children's success. This implies that education of girls who are from poor socio-economic backgrounds could be negatively affected leading to low transition rates of girls.

\section{Conclusions and Recommendations}

The study found out that social determinants such as girls' encouragement by parents on education issues and availability of role models influences transition rate of girls to secondary education. Lack of parental encouragement leads to low transition of girls from primary school to secondary schools. The study recommended therefore that there is need for teachers in primary schools to encourage girls to have role models. This is attributed to the fact that role models in education is associated with high transition rate among girls.

\section{Ethical Considerations}

The investigator sought for a research permit to conduct the research from the National Commission for Science, Technology and Innovations (NACOSTI), County director of Education and head teachers of the sampled primary schools before conducting the study. Participation of the respondents in the study was voluntary and free. In addition, there was no promise of benefits for taking part in the study and further the respondents were required to sign an informed consent letter before participating in the study. The study participants were guaranteed of their privacy and the confidentiality of the information they gave. Furthermore, the respondents were informed that they were free to withdraw from the study at any time they deem fit. 


\section{References:-}

1. Addulai, A. (2005, July 12). Lack of Fees affecting girls in Maasai, Daily Nation, Nairobi: Nation Media Group.

2. Alba de Souza, (2006). Reaching Nomadic Populations in Africa; A report from the Forum held in Garissa, Kenya in June 2006 Council for Education in the Commonwealth.

3. Ayiga N., (1997). Causes of Low Enrolment and High Dropout rate in Primary Education Among Female Children. Uganda, Academic Science Publishers.

4. Baxen, J., Nsubuga, Y. \& Botha, L. J. (2014). A capabilities perspective on education quality: Implications for foundation phase teacher education program design. Perspectives in Education, 32(4), 93-105.

5. Birdsall, N. Levine, A \&Ibrahim, A. (2005). Towards Universal Primary Education: Investments, Incentives and Institutions. New York: UNDP.

6. Brigeon, P. (2005, October). Schools Need to be a Safe Place for Girls. Education In sight magazine. Pg 14 col 2.

7. Case, A. \& Ardington, C. (2006). The impact of parental death on school outcomes: Longitudinal evidence from South Africa. Demography, 43(3), 401-420.

8. Chege, F. \& Sifuna, D.N. (2006). Girls and Women Education in Kenya: Gender Perspective and Trends. Available at http://books.google.co.ke. Retrieved on 22/11/13.

9. Chimombo, P. G. (2005). Issues in Basic Education in Developing Countries: An Exploration of Policy Options for Improved Delivery. Centre for Education, Research and Training: University of Malawi.

10. Creswell, J. W., \& Plano Clark V. L. (2007). Designing and Conducting Mixed Methods Research. Thousand Oaks, CA: Sage Publications.

11. Drummond, K.V. \& Stipek, D. (2004). Low-income parents' beliefs about their role in children's academic learning. The Elementary School Journal, 104 (3) 197-213.

12. Ebersohn, L. \& Eloff, I. (2002). The black, white and grey of rainbow children coping with HIV/AIDS. Perspectives in Education, 20(2), 77-86.

13. Fleming, K. E. (2015). Improving access to education for orphans or vulnerable children affected by HIV/AIDS. Paper commissioned for the EFA Global Monitoring Report 2015, Education for All 2000-2015: achievements and challenges. UNESCO. http://unesdoc.unesco.org/ images/ 0023/002324 /232423e.pdf.

14. GoK. (2005). Kenya Education Sector Support Programme2005-2010. Delivering Quality Education and Training to all Kenyans. Nairobi. Office of the President and Ministry of Home Affairs.

15. GoK. (2007). Gender Policy in Education, Nairobi: Government Printers. http://www.cse.standard/gender-gap in education.

16. Goodluck, I., \& Odaro, O. (2011). Issues in Girl-Child Education in Nigeria: Implications for Library and Information Support. Gender \& Behaviour, 9(2), 4139-4150.

17. Guyo, D. J (2013). School based factors affecting transition of girls from primary to secondary schools in Golbo Division, Moyale District. Unpublished Thesis, University of Nairobi.

18. Hallfors, D., Cho, H., Rusakaniko, S., Iritani, B., Mapfuno, J. \& Helpern, C. (2011). Supporting adolescent orphan girls to stay in school as HIV risk prevention: Evidence from a randomized controlled trial in Zimbabwe. American Journal of Public Health, 101(6), 1082-1088.

19. Henderson, A. T. \& Mapp, K. L. (2002). A new wave of evidence: The impact of school, family, and community connections on student achievement. Southwest Educational Development Laboratory National Center for Family and Community. Downloaded from http://www.sedl. org/connections/ resources/evidence.pdf

20. Houston, P. D. (2004). Outlook and perspectives on American education. London, UK: Scarecrow Education.

21. Huoblair, F. (2011). International Education Statistics. London: Macmillan Publishers.

22. Kariuki, N.M. (2007). Determinants of Enrolment and performance in Physics among Secondary Students of Maragua District, Kenya. Unpublished Med Thesis, Kenyatta.

23. Kasomo, D. (2001). Research methods in humanities and education. Kenya. Nairobi. Egerton University Press.

24. Kelly, M. J. (2002). Preventing HIV transmission through education. Perspectives in Education, 20(2), 1-12.

25. Kothari, C. R., (2008). Research Methodology: Methods and Techniques. (2 ${ }^{\text {nd }}$ Ed). Age, New Delhi, International publishers.

26. Krejcie, R.V, \& Morgan, D.W. (1970). Determining sample size for research activities. Educational \& Psychological measurement, 30, 607-610.

27. Ngware, M., Ezeh, E., Oketch, M. \& Mudenge, N.(2009). Do house hold characteristics matter in schooling decisions in Kenya? Equal Opportunities International 28 (7) 591-608.

28. Onyango, N. (2000). Factors that Influence Girls' Participation in Primary Schools: A Case Study of Nginyang and Marigat Divisions of Baringo District. (Master's Thesis) Kenyatta University, Kenya. 
29. Orodho, J. A. (2009). Elements of Education and Social Sciences Research Methods. Maseno, Kenya: Kanezja Publishers.

30. Republic of Kenya, (2007). Gender Policy in Education. Nairobi: Government Printer.

31. Robeyns, I. (2006). Three models of education: Rights, capabilities and human capital. Theory and Research in Education, 4(1), 69-84.

32. Sanders, M. G. \& Sheldon, S. B. (2009). Principals matter: A guide to school, family, and community partnerships. Corwin: A SAGE Company.

33. SEIA. (2007). At the Crossroads: Choices for Secondary Education in Sub-Saharan Africa. Washington D.C.: The World Bank.

34. Sheldon, S.B. (2009). In School, family, and community partnerships: Your handbook for action (3rd ed.). USA: Corwin Press.

35. Teske, P., Fitzpatrick, J., \& Kaplan, G. (2007). Opening doors: How low-income parents search for the right school. Washington, DC: Daniel J. Evans.

36. UNESCO, (2011). International Education Statistics: A situation analysis of the international position. UNESCO, Paris.

37. UNICEF (2005). 2005 and Beyond: Accelerating Girls' Education in South Asia. In: Arai, K., \& Tabata, Y. (2006). Socio-cultural factors affecting girls' limited access to school education in North West Frontier Province of Pakistan. November APERA Conference, Hong Kong (28-30).

38. UNICEF (2009). Promoting quality education for orphans and vulnerable children: A source book of programme experiences in Eastern and Southern Africa. UNICEF.

39. World Bank (2008). Transitions in Secondary Education in Sub-Saharan Africa Equity and Efficiency Issues. Working Paper No125, World Bank, Washington DC.

40. World Bank, (1988). Education in Sub-Sahara Africa, Policies for Adjustment Revitalization and Expansion: Washington D.C. The World Bank. 